\title{
Stress analysis of a single prosthesis on a poorly positioned implant
}

\author{
Análise de tensões em prótese unitária sobre implante mal posicionado \\ Análisis de tensión en prótesis unitaria sobre implantación molly posicionada
}

\author{
Francisco Carlos dos Santos Reis \\ ORCID: https://orcid.org/0000-0002-2489-9546 \\ Universidade Santo Amaro, Brazil \\ E-mail: prof.franciscoreis@gmail.com \\ William Cunha Brandt \\ ORCID: https://orcid.org/0000-0002-6362-0499 \\ Universidade Santo Amaro, Brazil \\ E-mail: williamcbrandt@yahoo.com \\ Letícia Cristina Cidreira Boaro \\ ORCID: https://orcid.org/0000-0002-6687-585X \\ Universidade Santo Amaro, Brazil \\ E-mail: leticiacidreiraboaro@gmail.com \\ Milton Edson Miranda \\ ORCID: https;//orcid.org/ 0000-0002-5410-6500 \\ Faculdade São Leopoldo Mandic, Brazil \\ E-mail:memiranda@memiranda.com.br
}

\begin{abstract}
The mechanical positioning behavior of a mal-positioned implant was evaluated in the finite element method. Models were created in SolidWorks Professional $2013^{\circledR}$ software with a single implant rehabilitation. The following were analyzed: Control Group, crown aligned to the implant long axis; Experimental Group, crown shifted $3 \mathrm{~mm}$ mesial proximally to the implant axis. Compressive stresses in cortical and medullary bone, and Von Mises stresses in implants and components were evaluated. With $100 \mathrm{~N}$ occlusal loading at 5 points. The peak von Mises stresses in the prosthetic screw of the experimental group (138.45 MPa) were $43.60 \%$ higher compared to the control group (96.41 MPa). The stresses in the prosthetic pillar were localized in the abutment region and the experimental group showed (875.63 MPa), $28 \%$ higher than the control group $(683.88 \mathrm{MPa})$. Regarding the implant, the maximum stress peaks were located in the implant platform and the experimental group showed stress values of (1081.4) MPa and was $26.42 \%$ higher than the control $855.39 \mathrm{MPa}$. The cortical bone tissue of the experimental group showed shear stress values $10.81 \%$ higher than the control. The stress values were $151.36 \mathrm{MPa}$ for the experimental group and (136.59 Mpa) for the control. The medullary bone showed shear stress (8.31 MPa) and was $12.29 \%$ higher than the control (7.40 MPa). A maximum peak was obtained in the cervical region of the medullary bone, adjacent to the cortical bone. The experimental group with a mal-positioned implant showed the highest maximum stresses for all simulated prosthetic components.
\end{abstract}

Keywords: Dental implants; Finite element analysis; Prosthodontics.

\section{Resumo}

O comportamento mecânico posicionamento de um implante mal posicionado foi avaliado no método de elementos finitos. Modelos foram criados no software SolidWorks Professional 2013 ${ }^{\circledR}$, com uma reabilitação unitária sobre implante. Foram analisados: Grupo Controle, coroa alinhada ao longo eixo do implante; Grupo experimental, Coroa deslocada $3 \mathrm{~mm}$ para a região proximal mesial em relação ao eixo do implante. Avaliaram-se tensões de compressão em osso cortical e medular, e Von Mises em implantes e componentes. Com carga oclusal de $100 \mathrm{~N}$, em 5 pontos. Os picos de tensão de von Mises do parafuso protético do grupo experimental (138,45 MPa) apresentaram tensão 43,60\% superior, comparado ao grupo controle $(96,41 \mathrm{MPa})$. Já no pilar protético as tensões foram localizadas na região do pilar e o grupo experimental apresentou $(875,63 \mathrm{Mpa})$ e foi $28 \%$ maior que o controle $(683,88 \mathrm{Mpa})$. Em relação ao implante, os picos máximos de tensão localizaram-se na plataforma do implante e o grupo experimental apresentou valores de tensão de $(1081,4) \mathrm{MPa}$ e foi $26,42 \%$ superior ao do controle $855,39 \mathrm{MPa}$. O tecido ósseo cortical do grupo experimental apresentou valores de tensão de cisalhamento $10,81 \%$ superiores ao controle. Os valores de tensão foram de 151,36 MPa para o grupo experimental e (136,59 Mpa) para o controle. O osso medular apresentou tensão de cisalhamento $(8,31 \mathrm{MPa})$ e foi $12,29 \%$ superior ao controle $(7,40 \mathrm{MPa})$. Obteve-se pico máximo, na região cervical do osso medular, adjacente ao osso cortical. O grupo experimental com implante mal posicionado, apresentou as maiores tensões máximas para todos os componentes protéticos simulados.

Palavras-chave: Implante dentário; Análise em elementos finitos; Prótese dentária. 


\section{Resumen}

El comportamiento mecánico de la colocación de un implante mal colocado mediante el método de elementos finitos. Los modelos se crearon en el software SolidWorks Professional $2013^{\circledR}$, con rehabilitación unitaria sobre implante. Se analizaron: Grupo Control, corona alineada con el eje mayor del implante; Grupo experimental, corona desplazada 3 $\mathrm{mm}$ a la región mesial en relación con el eje del implante. Se evaluaron las tensiones de compresión en el hueso cortical y medular y Von Mises, con carga oclusal de 100N, en 5 puntos. Los picos de tensión de von Mises del tornillo protésico en el grupo experimental (138,45 MPa) presentaron un 43,60\% más de tensión, en comparación con el control (96,41 $\mathrm{MPa})$. En el pilar protésico, las tensiones se ubicaron en la región del pilar y el grupo experimental $(875,63 \mathrm{Mpa})$ y fue un $28 \%$ mayor que el control $(683,88 \mathrm{Mpa})$. En relación al implante, los picos de tensión máxima se ubicaron en la plataforma del implante y el grupo experimental valores de tensión de $(1081,4)$ MPa y fue un 26,42\% superior al control de 855,39 MPa. El tejido cortical del grupo experimental presentó valores de esfuerzo cortante un $10,81 \%$ superiores al control. Los valores de tensión fueron de 151,36 MPa para el grupo experimental y (136,59 MPa) para el control. El hueso medular mostró un esfuerzo cortante $(8,31 \mathrm{MPa})$ y un $12,29 \%$ más alto. Se obtuvo pico máximo en la región cervical. El grupo experimental presentó las tensiones máximas más altas para todos los componentes protésicos.

Palablas clave: Implantes dentales; Análisis de elementos finitos; Prótesis dental.

\section{Introduction}

In current dentistry, several rehabilitation possibilities such as fixed, removable prostheses or dental implants have proven to be effective in the face of loss of mastigatory function by edentulous patients. According to the Quirynen et al. (2015), Sargolzaie et al. (2017), Filius et al. (2018) when comparing an implant-retained prosthesis with removable prostheses, there is considerably increased patient satisfaction and quality of life with consequent psychological and social well-being, masticatory function, speech, nutrition, and stagnation in the resorption of the alveolar process.

Therefore, according to Torrecillas-martinez et al. (2014), Max et al. (2015) and Ozan \& Kurtulmus-Yilmaz (2018) some conditions such as pneumatization of the maxillary sinuses or bone atrophies are impediments to a proper positioning of the implants, and in order to confer ideal interlocking and proper implant installation, many forms of regeneration, such as intraoral and extraoral grafts, have been proposed, bringing with them complications such as bleeding, infection, and paresthesia. Thus, other options have been alternatives, such as short, inclined or cantilevered implants, which are defined as a beam in which any similar structure protrudes outward, supported only at one end.

However, according to Quirynen et al. (2015) and Drago (2016), cantilevers act as a lever arm causing greater structural bending and stress on implants, prosthetic components and perimplant bone, having the capacity for bone resorption as well as, prosthetic complications. Pjetursson et al. (2007), Max et al. (2015) and Premnath et al. (2020) concluded that cantilevers in implant prostheses although not related to loss of osseointegration have a negative influence on treatment prognosis, with an increase in technical complications, such as screw or component loosening, fracture of the covering material, bone resorption and perimplantitis.

According to Zurdo et al. (2009), Schmid et al. (2020), Papaspyridakos et al. (2020) and (Huang \& Wang, 2019), although prosthetics on implants are clinically and scientifically consolidated, some challenges indicate the need for analysis and studies, since numerous technical and biological complications are common, such as screw loosening, porcelain cover fracture and bone loss. Aiming to understand these occurrences, this study evaluated, by means of three-dimensional finite element analysis (FEM), the biomechanical behavior of abutments, screws and bone in the face of a malpositioned implant in a single implant in the posterior region of the mandible, using as null hypothesis the non-increase of stresses in the evaluated elements.

\section{Methodology}

Two geometric models were generated using SolidWorks $2013^{\circledR}$ software (Solidworks Dassault Systems, Watham, Massachusetts, USA) for three-dimensional modeling, being a control group (in which the crown is positioned aligned with the 
longitudinal axis of the implant) and an experimental group (crown $3 \mathrm{~mm}$ off center, mesial to the longitudinal axis of the implant (Figure 1.a).

Based on anatomical references and measurements available in the literature (Table 1), a single rehabilitation in the posterior region of the mandible was simulated and to build the bone models, anatomical contours referring to a section of the posterior region of a mandible were used (Figure 1.b).

A 3.8 x 10m Infra System cone morse platform implant (Signovinces, Campo Largo, Parana, Brazil) was positioned in the region corresponding to the lower first molar, $1 \mathrm{~mm}$ below the alveolar bone crest. A concentrically aligned conical abutment and, likewise, a prosthetic screw were positioned over it.

Table 1 - Modulus of elasticity and Poison's coefficient used to characterize the behavior of the materials.

\begin{tabular}{llll}
\hline Material & $\begin{array}{l}\text { Modulus of Elasticity } \\
\text { (MPa) }\end{array}$ & Poison Coefficient & Referência \\
\hline Cortical bone & 13,700 & 0,30 & Teixeira et al. (1998) \\
Medullar bone & 1,370 & 0,30 & Teixeira et al. (1998) \\
Titanium (Ti6A14V) & 110,000 & 0,35 & Teixeira et al. (1998) \\
\hline
\end{tabular}

Source: Own authorship.

To create the prosthetic crown, anatomical measurements were used to model a dental element corresponding to the lower first molar. To achieve a perfect fit between the crown and abutment base, the "entity loft" tool was used, which uses the abutment base as a reference for seating the crown. The parts were matched to each other using the subtraction matching feature, which allows the internal adjustment of the parts without generating interferences that could prejudice the numerical interpretation of the analysis. The experimental group was obtained by controlled mesial displacement of the prosthetic crown followed by adaptation to the abutment base (Figure 1.c).

The assembly was reconstructed in the assembly environment of SolidWorks software (Solidworks Dassault Systems, Watham, Massachusetts, USA) and exported for the analysis (Figure 1.d). The model was imported by AnsysWorkbench software (ANSYS Inc, Canonsburg, Pennsylvania, USA) into the static structural analysis environment. It was necessary to discretize the model which was performed by using mechanical properties such as modulus of elasticity and Poison's coefficient according to previously published works (Camargo et al., 2018), (Zheng et al., 2012), Dittmer et al. (2010).

Previously to the analysis, it is necessary to divide the model into smaller elements by means of a mesh. These elements are interconnected to other elements by means of nodes. The present study used the mesh quality criterion, where consecutive refinements were performed in order to obtain a greater number of elements with a score equal to 1.0. The control group generated 962.480 nodes and 669.332 elements, whereas, the experimental group generated 955.030 nodes and 662.057 elements. The bone model was fixed on the lateral faces and base to simulate the union to the rest of the mandible. In addition, the purpose of the fixation is to prevent displacement of the model during load application.

A load of $100 \mathrm{~N}$ was applied to the occlusal surface of the crown divided into 5 points. The loads were tilted 10 degrees relative to the long axis of the implant in order to simulate contact followed by sliding (Figure 2).

The data obtained were evaluated according to maximum shear stress criteria for cortical and medullary bone tissue, tensile stress for crown, and von Mises stress for implant, abutment, and prosthetic screw. The pattern of force distribution was compared qualitatively between the models, where the maximum peak (highest stress value) is represented by red color. 
Figure 1 - A) Control group in the center of the longitudinal axis of the implant and experimental group with the crown displaced $3 \mathrm{~mm}$ mesially. B) Complete model in bone tissue representative of the region. C) Creation of the experimental model using the move/copy tool. D) Top view of the complete models (a) control and (b) experimental.

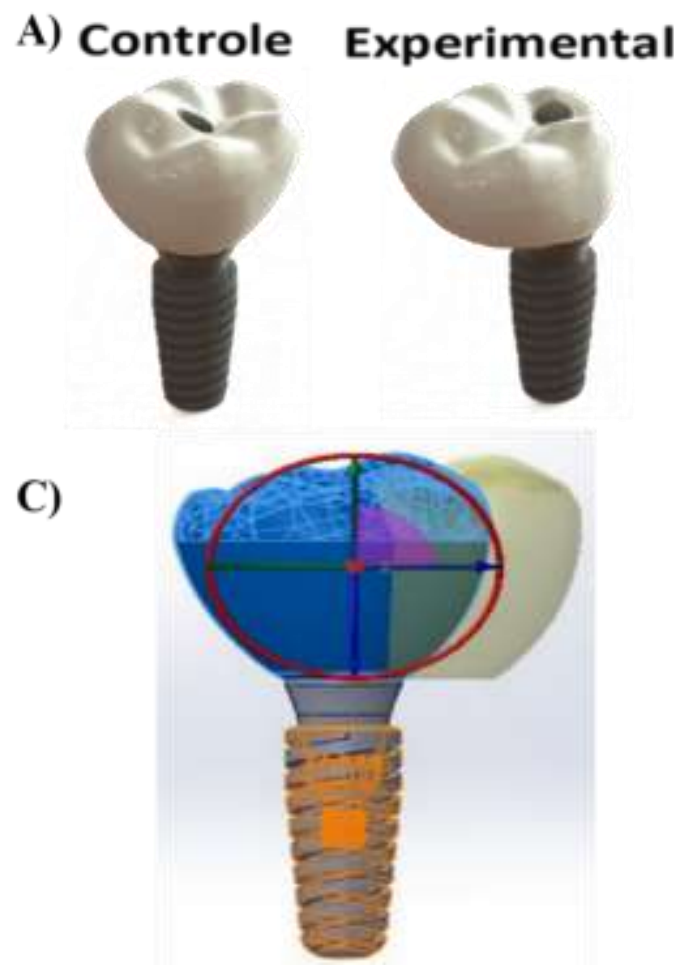

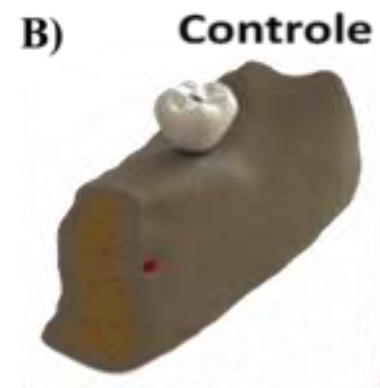

D)

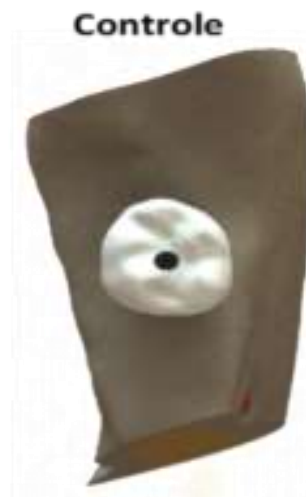

Experimental

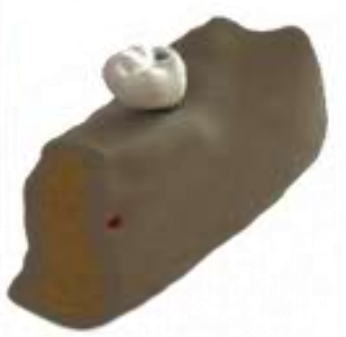

Experimental

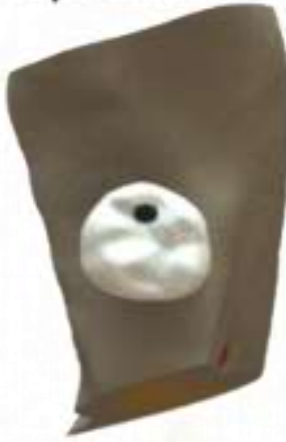

Source: Own authorship.

Figure 2 - Points of occlusal application of loading.

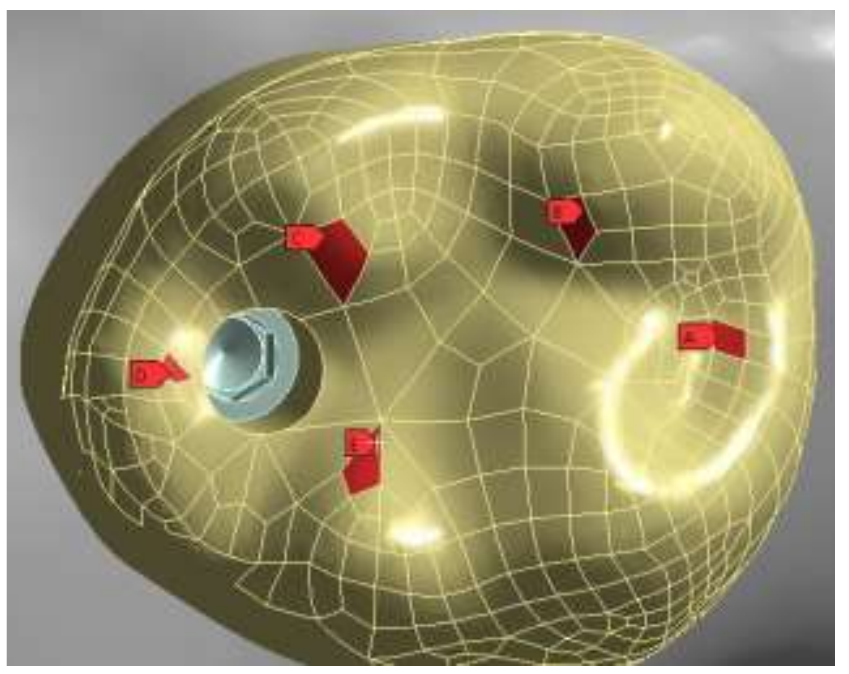

\section{Results}

Source: Own authorship.

After verification of the data through quantitative and qualitative analysis, the results were divided for individual evaluation of the stress generated in each region: bone tissues, implants, abutments, abutment screws, and prosthesis. The data obtained regarding maximum stress are shown in Table 2. 
Table 2 - Maximum value obtained according to the von Mises stress criterion for prosthetic components and shear for bone tissue $(\mathrm{MPa})$.

\begin{tabular}{llcc}
\hline & Control & Experimental & $\%$ \\
\hline von Mises Bolt & 96,41 & 138,45 & $43,60 \%$ \\
von Mises Abutment & 683,88 & 875,63 & $28 \%$ \\
von Mises Implant & 855,39 & 1081,4 & $26,42 \%$ \\
Cortical Bone Shear & 136,59 & 151,36 & $10,81 \%$ \\
Medullar Bone Shear & 7,40 & 8,31 & $12,29 \%$ \\
\hline
\end{tabular}

Source: Own authorship.

The peaks of von Mises stress of the prosthetic screw, prosthetic abutment, and implant platform, and the corresponding qualitative test stress values presented in Figure 3.

Figure 3 - A) von Mises stress in the prosthetic screw highlighted in the black square highlighting the region of the threads. B) Region of the threads of the prosthetic screw of the experimental group, demonstrating the maximum peak of stress (red color). C) von Mises stress in the abutment, observing the maximum peak of stress concentration in the region in contact with the implant. D) Shear stress in the cortical bone located in the region in contact with the first implant threads (image in section). E) Maximum peak von Mises stress located in the implant platform near the internal region. F) Shear stress in the medullary bone.

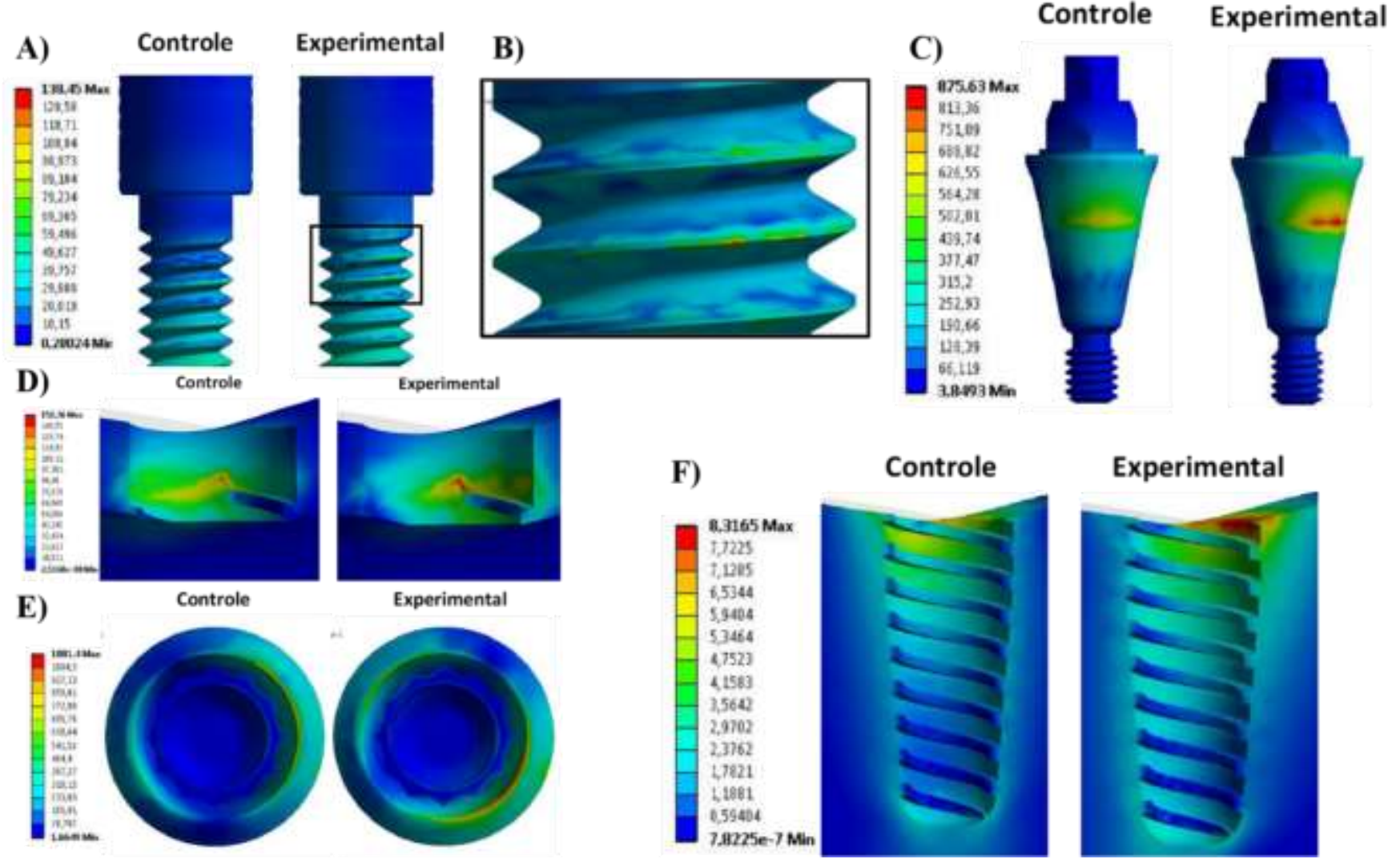

Source: Own authorship. 


\section{Discussion}

Planning for implant installation is essential, however, often due to anatomical limitations such as pronounced resorption of the maxillae and consequent approximation of important structures such as the maxillary sinus, nasal fossa, mentual foramen and even the inferior alveolar nerve, This procedure aims to simplify planning, thus avoiding extensive surgeries, minimizing costs and morbidity (Alom et al., 2021; da Silva et al., 2018; Manea et al., 2019; Muangsisied et al., 2021).

The null hypothesis of absence of increased stresses in the evaluated elements was refuted in view of the results achieved in the present study, that in an extension of $3 \mathrm{~mm}$, stresses increased due to the incorrect mesio-distal positioning of the implant. There was an increase in the peak von Mises stress of $40.6 \%$ in the prosthetic screw and $28 \%$ in the abutment (Figures 3.a and 3.b). These results converge with studies showing the screw and prosthetic abutment regions as the most affected with complications such as loosening and fracture (Ramos et al., 2014; Pjetursson et al., 2007; Drago, 2016; Rodrigues et al., 2019). Although Torrecillas-martinez et al. (2014) and Camargo et al. (2018) argued that despite minute technical intercurrences, the presence of extension did not affect the success rate of the prostheses.

The von Mises stress of the prosthetic abutment was localized in the transmucosal region, close to the implant platform. Uniform distribution in the rest of the abutment body (Figure 3.c). The experimental group showed $875.63 \mathrm{MPa}$ and was $28 \%$ greater than the control group (683.88 MPa), a result similar to that of Alom et al. (2021), who, when analyzing a buccal cantilever in a single prosthesis, found greater stress in the abutment of the group tested.

In the present study, an increase in shear stress in the cortical bone of $10.81 \%$ was obtained in the experimental group, in the cervical region of the implant near the first threads, and in the medullary bone of $12.29 \%$, which may suggest an increased risk of osseointegration loss in poorly positioned implants (Figure 3.d, 3.e 3.f). Schmid et al. (2020) and Zurdo et al. (2009) reported that bone loss tends to increase in cantilever-associated implants, however Hasan et al. (2014) stated that although there is maximization of stresses in cancellous bone under functional loading, greater importance should be given to the bone thickness in which the implant will be installed.

In this study, the peak stress of the prosthetic abutment was located in the transmucosal region, close to the implant platform. The experimental group presented with incorrect implant positioning, 28\% higher than the control group. In a similar study, Tang et al. (2012) applied a $170 \mathrm{~N}$ force with $45^{\circ}$ angulation and obtained increased stresses, mainly in the gingival profile region of the abutment and in the first threads of the implant, although they concluded that it is unlikely that this magnification results in failures that make the rehabilitation unfeasible. Regarding the abutment, Suedam et al. (2016) suggest minimizing the abutment length in order to reduce stresses, decreasing the lever arm, in addition to using stiffer alloys for making the prosthesis with the purpose of favoring a better distribution of stresses through the implant and components.

Desai et al. (2015), when performing an FEM study to evaluate the best thread configuration in several implants found in the market, stated that the key factor for the collapse or success of an implant is the way in which stresses are transferred to the perimplant bone, and trapezoidal threads obtained the best biomechanical performance. However, Mosavar et al. (2015), using a similar methodology, concluded that the various thread configurations did not affect stress distribution patterns in the bone, and that this was not the predominant factor. In the implant used in this study, the threads are trapezoidal, with the cortical bone tissue of the experimental group exhibiting $10.81 \%$ higher shear stress when compared to the control group. The maximum stress was located in the first threads of the implant in both the medullary and cortical bone (Figure 3.d; 3.e and 3.f).

Aglietta et al. (2012) understand that there is no fear in the use of cantilevers, in which they corroborate Premnath et al. (2020), Camargo et al. (2018) and (Greenstein \& Cavallaro JR, 2010) stating that the cantilever is another alternative in planning for rehabilitation in the face of conditions in which the absence of bone and anatomical structures prevent the installation of an implant for each crown. Halg et al. (2008) concluded that there is no clinical correlation between the use of cantilever extensions and bone loss or failure of the implants supporting them, and that this increase in stress is tolerated by the system and dissipated 
by the numerous materials it is composed of: titanium, abutments, screws, infrastructure $(\mathrm{CrCo})$ or cover materials (ceramic or resin). Although the results found do not correlate perimplant bone loss with cantilever, the present study, with increased stresses in all elements analyzed, suggest risk in rehabilitations with cantilever mainly regarding prosthetic complications such as screw loosening, abutment loosening and material fracture probably accompanied by long-term clinical compromise.(da Silva et al., 2018) (Storelli et al., 2018)

This study was exclusively laboratory, thus clinical studies are needed to elucidate the gap of how the influence of the cantilever due to improper positioning of the single implant, acts on the long-term rehabilitation.

\section{Conclusion}

In the present study it can be stated that in the experimental model with the implant in the wrong position, the influence of the cantilever showed the highest stresses for all components involved in the prosthetic rehabilitation, simulated in comparison to the control group. Complementary studies addressing the clinical effect of this increase in tensions may be of great importance in rehabilitation.

\section{References}

Aglietta, M., Blasi, A., \& Salvi, G. E. (2012). Clinical and radiographic changes at implants supporting single-unit crowns ( SCs ) and fixed dental prostheses (FDPs ) with one cantilever extension . A retrospective study. 1-6. https://doi.org/10.1111/j.1600-0501.2011.02391.x

Alom, G., Kwon, H. B., Lim, Y. J., \& Kim, M. J. (2021). Three-dimensional finite element analysis of buccally cantilevered implant-supported prostheses in a severely resorbed mandible. Journal of Advanced Prosthodontics, 13(1), 12-23. https://doi.org/10.4047/jap.2021.13.1.12

Camargo, B., Drummond, L., Ozkomur, A., Villarinho, E., Rockenbach, M., Teixeira, E., \& Shinkai, R. (2018). Implant Inclination and Cantilever Length Are Not Associated with Bone Loss in Fixed Complete Dentures: A Prospective Study. The International Journal of Prosthodontics, 32(1), 17-19. https://doi.org/10.11607/ijp.6022

da Silva, E., dos Santos, D., Sonego, M., Gomes, J., Pellizzer, E., \& Goiato, M. (2018). Does the Presence of a Cantilever Influence the Survival and Success of Partial Implant-Supported Dental Prostheses? Systematic Review and Meta-Analysis. The International Journal of Oral \& Maxillofacial Implants, 33(4), 815823. https://doi.org/10.11607/jomi.6413

Desai, S. R., Desai, M. S., Katti, G., \& Karthikeyan, I. (2015). Evaluation of design parameters of eight dental implant designs : A two - dimensional finite element analysis. June. https://doi.org/10.4103/1119-3077.97308

Drago, C. (2016). Cantilever Lengths and Anterior-Posterior Spreads of Interim, Acrylic Resin, Full-Arch Screw-Retained Prostheses and Their Relationship to Prosthetic Complications. 00, 1-6. https://doi.org/10.1111/jopr.12426

Filius, M. A. P., Vissink, A., Cune, M. S., Raghoebar, G. M., \& Visser, A. (2018). Effect of implant therapy on oral health-related quality of life (OHIP-49), health status (SF-36), and satisfaction of patients with several agenetic teeth: Prospective cohort study. Clinical Implant Dentistry and Related Research, 20(4), 592-597. https://doi.org/10.1111/cid.12625

Greenstein, G., \& Cavallaro JR, J. (2010). ABSTRACT. The Journal of the American Dental Association, 141(10), 1221-1230. https://doi.org/10.14219/jada.archive.2010.0049

Halg, G. A., Schmid, J., \& Hammerle, C. H. F. (2008). Bone level changes at implants supporting crowns or fixed partial dentures with or without cantilevers. 983-990. https://doi.org/10.1111/j.1600-0501.2008.01556.x

Hasan, I., Heinemann, F., \& Bourauel, C. (2014). Biomechanical finite element analysis of self-tapping implants with different dimensions inserted in two bone qualities. 59(3), 203-211. https://doi.org/10.1515/bmt-2013-0109

Huang, Y., \& Wang, J. (2019). Mechanism of and factors associated with the loosening of the implant abutment screw: A review. Journal of Esthetic and Restorative Dentistry, 31(4), 338-345. https://doi.org/10.1111/jerd.12494

Manea, A., Bran, S., Dinu, C., Rotaru, H., Barbur, I., Crisan, B., Armencea, G., Onisor, F., Lazar, M., Ostas, D., Baciut, M., Vacaras, S., Mitre, I., Crisan, L., Muresan, O., Roman, R., \& Baciut, G. (2019). Principles of biomechanics in oral implantology. Medicine and Pharmacy Reports, 92(3), 14-19. https://doi.org/10.15386/MPR-1512

Max, A., Walter, C., Ehbauer, S., Zwiener, I., Ziebart, T., Al-nawas, B., \& Oliver, M. (2015). Analysis of implant-failure predictors in the posterior maxilla : A retrospective study of 1395 implants. Journal of Cranio-Maxillofacial Surgery, 1-7. https://doi.org/10.1016/j.jcms.2015.01.004

Mosavar, A., Ziaei, A., \& Kadkhodaei, M. (2015). The Effect of Implant Thread Design on Stress Distribution in Anisotropic Bone with Different Osseointegration Conditions : 1317-1326. https://doi.org/10.11607/jomi.4091

Muangsisied, S., Chantarapanich, N., Veerasakul, M. S., \& Inglam, S. (2021). Effect of implant diameter and cortical bone thickness on biomechanical performance of short dental implant-supported distal cantilever: A finite element study. Engineering Journal, 25(2), $175-182$. 
Research, Society and Development, v. 10, n. 11. e579101119815, 2021

(CC BY 4.0) | ISSN 2525-3409 | DOI: http://dx.doi.org/10.33448/rsd-v10i11.19815

https://doi.org/10.4186/ej.2021.25.2.175

Ozan, O., \& Kurtulmus-Yilmaz, S. (2018). Biomechanical Comparison of Different Implant Inclinations and Cantilever Lengths in All-on-4 Treatment Concept by Three-Dimensional Finite Element Analysis. The International Journal of Oral \& Maxillofacial Implants, 33(1), 64-71. https://doi.org/10.11607/jomi.6201

Papaspyridakos, P., Bordin, T. B., Kim, Y. J., El-Rafie, K., Pagni, S. E., Natto, Z. S., Teixeira, E. R., Chochlidakis, K., \& Weber, H. P. (2020). Technical Complications and Prosthesis Survival Rates with Implant-Supported Fixed Complete Dental Prostheses: A Retrospective Study with 1- to 12-Year FollowUp. Journal of Prosthodontics, 29(1), 3-11. https://doi.org/10.1111/jopr.13119

Pjetursson, B. E., Bra, U., Lang, N. P., \& Zwahlen, M. (2007). Comparison of survival and complication rates of tooth-supported fixed dental prostheses ( FDPs ) and implant-supported FDPs and single crowns ( SCs ). 97-114. https://doi.org/10.1111/j.1600-0501.2007.01439.x

Premnath, D. K., Prakash, D. N., Tilak, D. B., R, D. K., MP, D. S., \& Rheel, D. S. A. (2020). Evaluation of surrounding anatomical structures in implant supported FPD with and without cantilever: An original research. International Journal of Applied Dental Sciences, 6(4), 289-291. https://doi.org/10.22271/oral.2020.v6.i4e.1078

Quirynen, T., Quirynen, M., \& Duyck, J. (2015). Prevention of distal extension cantilever fracture in mandibular overdentures . Elsevier Ltd. https://doi.org/10.1016/j.jdent.2015.06.007

Ramos, B., Albrektsson, T., \& Wennerberg, A. (2014). ScienceDirect Tilted versus axially placed dental implants : A meta-analysis. Journal of Dentistry. https://doi.org/10.1016/j.jdent.2014.09.002

Rodrigues, I., Zanardi, P., \& Sesma, N. (2019). Effect of Abutment Screw Design and Crown/Implant Ratio on Preload Maintenance of Single-Crown ScrewRetained Implant-Supported Prostheses. The International Journal of Oral \& Maxillofacial Implants, 34(6), 1397-1403. https://doi.org/10.11607/jomi.7311

Sargolzaie, N., Moeintaghavi, A., \& Shojaie, H. (2017). Comparing the Quality of Life of Patients Requesting Dental Implants Before and After Implant. The Open Dentistry Journal, 11(1), 485-491. https://doi.org/10.2174/1874210601711010485

Schmid, E., Morandini, M., Roccuzzo, A., Ramseier, C. A., Sculean, A., \& Salvi, G. E. (2020). Clinical and radiographic outcomes of implant-supported fixed dental prostheses with cantilever extension. A retrospective cohort study with a follow-up of at least 10 years. Clinical Oral Implants Research, 31(12), 12431252. https://doi.org/10.1111/clr.13672

Storelli, S., Del Fabbro, M., Scanferla, M., Palandrani, G., \& Romeo, E. (2018). Implant supported cantilevered fixed dental rehabilitations in partially edentulous patients: Systematic review of the literature. Part I. Clinical Oral Implants Research, 29(May), 253-274. https://doi.org/10.1111/clr.13311

Suedam, V., Tobias, R., Neto, M., Antonio, E., Sousa, C., Rubo, J. H., Rq, J., Shul, W. K. H., Duhd, L., Fdqwlohyhuhg, R. I., Vxssruwhg, L., Sduwldo, H. G., Wr, D., Rffoxvdo, W. K. H., Ri, V., Fldo, D., \& Lv, W. (2016). on the stress distribution in peri-implant area RI FDQWLOHYHUHG LPSODQW VXSSRUWHG ¿[ HG SDUWLDO dentures. 6(2013), 114-120.

Tang, C., Liu, S., Zhou, G., Yu, J., Zhang, G., Bao, Y., \& Wang, Q. (2012). Nonlinear finite element analysis of three implant - abutment interface designs. April, 101-108. https://doi.org/10.1038/ijos.2012.35

Torrecillas-martinez, L., Monje, A., Catalunya, U. I. De, Lin, G., \& Francisco, S. (2014). Effect of Cantilevers for Implant-Supported Prostheses. August. https://doi.org/10.11607/jomi.3660

Zheng, Z., Lin, J., Shinya, A., Matinlinna, J. P., Botelho, M. G., \& Shinya, A. (2012). Finite element analysis to compare stress distribution of gold alloy, lithiumdisilicate reinforced glass ceramic and zirconia based fixed partial denture. Journal of Investigative and Clinical Dentistry, 3(4), 291-297. https://doi.org/10.1111/j.2041-1626.2012.00167.x

Zurdo, J., Wennstro, J. L., \& Roma, C. (2009). Survival and complication rates of implant-supported fixed partial dentures with cantilevers : a systematic review. 59-66. https://doi.org/10.1111/j.1600-0501.2009.01773.x 